\title{
Composition and structure of the helminth community of Columba livia (Gmelin, 1798) (Aves, Columbidae), in the municipality of Juiz de Fora, Minas Gerais state, Brazil
}

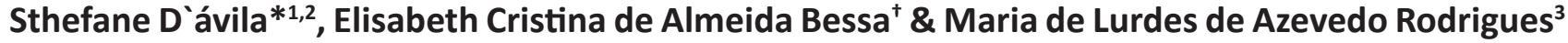 \\ ${ }^{1}$ Museu de Malacologia Prof. Maury Pinto de Oliveira, Instituto de Ciências Biológicas, Universidade Federal de \\ Juiz de Fora, Juiz de Fora, Brasil. *Corresponding author-sthefanedavila@hotmail.com \\ ${ }^{2}$ Departamento de Zoologia, ICB, UFJF. \\ ${ }^{3}$ Departamento de Parasitologia Animal, Curso de Pós Graduação em Ciências Veterinárias, Universidade \\ Federal Rural do Rio de Janeiro, Seropédica, Brasil.
}

\begin{abstract}
The objective of the present study was to describe the composition and structure of the helminth community present in domestic pigeons, in the municipality of Juiz de Fora, Minas Gerais, Brazil. The helminthological survey of 35 hosts revealed the presence of two digenetic trematodes, Tanaisia (Paratanaisia) bragai (prevalence 51.42\%, mean intensity $288.8 \pm 403.86$ and mean abundance $148 \pm 320.9$ ) and T. inopina (prevalence $2.85 \%$ and mean abundance $0.68 \pm 4.05$ ); five cestodes, Raillietina allomyodes (prevalence $34.28 \%$, mean intensity $6.66 \pm 9.14$ and mean abundance $2.28 \pm 6.11$ ), Raillietina sp. (prevalence $37.14 \%$, mean intensity $9 \pm 10.68$ and mean abundance $3.34 \pm 7.7$ ), Skrjabinia bonini (prevalence 20\%, mean intensity $2.14 \pm 1.21$ and mean abundance $0.42 \pm 1$ ), Skrjabinia sp.( prevalence 5.7\%, mean intensity $6 \pm 7$ and mean abundance $0.34 \pm 7$ ) and Fuhrmanneta sp. (prevalence $2.85 \%$ and mean abundance $0.028 \pm 0.16$ ) and four nematodes, Baruscapillaria obsignata (prevalence 51.42\%, mean intensity $29.72 \pm 44.2$ and mean abundance $15.28 \pm 34.7$ ); Ascaridia columbae (prevalence 51.42\%, mean intensity $60.55 \pm 79.88$ and mean abundance $31.14 \pm 64.2$ ); Tetrameres fissipina (prevalence 14.28\%, mean intensity $346.3 \pm 504.4$ and mean abundance $49.42 \pm 212.1$ ) and Synhimanthus (Dyspharynx) nasuta (prevalence $2.85 \%$ and mean abundance $0.028 \pm 0.16$ ). Among the examined hosts, $97.2 \%$ were found parasitized by at least one helminth species. In accordance with the prevalence of each species T. bragai, A. columbae and B. obsignata were considered secondary species and T. inopina, T. fissipina, S. nasuta, S. bonini, Skrjabinia sp., R. allomyodes, Raillietina sp. and Fuhrmanneta sp. were considered satellite species. All the species exhibited aggregate distributions, which is the most common distribution pattern in helminth populations.
\end{abstract}

Key words: aggregation, distribution, domestic pigeons, ecology, helminth fauna, prevalence. 


\section{INTRODUCTION}

The knowledge on helminth fauna of Columba livia (Gmelin 1798) (Columbidae) in Brazil was initiated with the investigation of parasitism in domestic animals, which lead to the publication of lists of helmith species, their hosts and geographical distributions. Besides helminth fauna investigation, early studies focused on taxonomy, new species descriptions and occurrence and prevalence reports.

COSTA \& FREITAS (1970) published a list of helminth parasites of domestic animals in Brazil, reporting, Ascaridia columbae (Gmelin, 1750) (Nematoda, Ascaridiidae), Capillaria columbae (Rudolphi, 1815) (Nematoda, Capilariidae), Dispharynx spiralis (Molin, 1858) (Nematoda, Acuariidae) Tetrameres fissipina Diesing, 1861 (Nematoda, Tetrameridae), Raillietina bonini (Megnin, 1899) (Cestoda, Davaineidae) and Tanaisia bragai (Santos, 1934) (Digenea, Eucotylidae) as parasites of $C$. livia. CARNEIRo et al. (1975) registered A. columbae, T. bragai, C. columbae, Raillietina sp. and $T$. confusa infecting domestic pigeons in the municipality of Goiânia, Goiás state. COSTA et al. (1986) reported the presence of $C$. columbae, A. columbae, Raillietina allomyodes e $R$. bonini, in the intestine, and $T$. bragai in the urinary tract of $C$. livia, in most of the Brazilian states. SILVA (1990) accounted for the parasitism in $C$. livia by $D$. spiralis (prevalence $2.8 \%)$, R. bonini (45.71\%), T. bragai (42.85\%), C. columbae (25.7\%) and A. columbae (11.42\%), in the municipality of São Gonçalo, Rio de Janeiro state.
Recently, the majority of the studies are related to either the pathology in the definitive host or the life cycles of the helminthes of columbiform birds.

Considering the lack of data on the helminth community ecology in C. livia, the objective of this study is to describe the helminth community structure in C. livia at infracommunity and component community levels.

\section{MATERIAL AND METHODS}

Thirty-five domestic pigeons (C. livia) from the municipality of Juiz de Fora were necropsied and examined for helminth parasites. All organs and corporal cavities were examined. The specimens found were collected and prepared according to the conventional helminthological techniques (АмATO et al. 1991) and subsequently identified and quantified.

The ecological terminology employed in this study was that recommended by BusH et al. (1997). The following statistical procedures and ecological indexes were used to define helminth community structure: variance to mean ratio test for each species of helminth, to determine the distribution pattern of the infrapopulations; Simpson's index for concentration for dominance (dominance was assumed when $c^{3}$ 0.25). The core-satellite species concept first utilized for helm inth parasite communities by BUSH \& HOLMES (1986a, 1986b) was applied. The components of the infra communities were classified in core species (present in more than two thirds of the hosts), secondary species (present in one to two 
thirds of the hosts) and satellite species (present in less than one third of the hosts).

The components were also defined by attributing importance values, based in abundance and prevalence of the species (THUL et al. 1985). Brillouin index $(H)$ for diversity was calculated for each infracommunity, including the species with prevalence higher than $10 \%$ (BUSH \& HOLMES 1986). Spearman coefficient of correlation $(p<0.05)$ was calculated to determine the correlation between abundance of the species that occurred in the same organ.

\section{RESULTS}

\section{COMPONENT COMMUNITY}

Among the 35 hosts examined, 34 were parasitized by at least one helminth species, corresponding to a prevalence of $97.2 \%$. A total of 8805 helminth specimens were collected, consisting of 225 cestodes, 3356 nematodes and 5224 digenetic trematodes.

We registered an average of 251.5 \pm 401.5 parasites per infected host, with abundance amplitude of 1-1517. The infected hosts presented on average $8.3 \pm 11.3$ cestodes; $95.8 \pm 214.1$ nematodes and $290 \pm 403.3$ digenetic trematodes. The digenetic trematodes corresponded to $59.32 \%$ of the total number of helminthes collected and thus it was the most important taxon, with mean abundance of 149.2 \pm 320.9 .

The cestodes corresponded to $2.55 \%$ of the helminth specimens collected, with mean abundance of $6.42 \pm 10.5$ and the nematodes corresponded to $38.11 \%$, with mean abundance of $95.9 \pm 214.1$.

The identification of collected specimens revealed the presence of two digenetic trematodes, Tanaisia (Paratanaisia) bragai (Santos, 1934) (Eucotylidae) (prevalence $51.42 \%$, mean intensity $288.8 \pm 403.86$ and mean abundance $148 \pm 320.9)$ and T. inopina Freitas, 1951 (Eucotylidae) (prevalence 2.85\% and mean abundance $0.68 \pm 4.05$ ); five cestodes, Raillietina allomyodes Kotlán, 1921 (Davaineidae) (prevalence $34.28 \%$, mean intensity $6.66 \pm 9.14$ and mean abundance $2.28 \pm 6.11$ ), Raillietina sp. (prevalence $37.14 \%$, mean intensity $9 \pm 10.68$ and mean abundance $3.34 \pm 7.7$ ), Skrjabinia bonini (Davaineidae) (prevalence 20\%, mean intensity $2.14 \pm 1.21$ and mean abundance $0.42 \pm 1$ ), Skrjabinia sp. (prevalence 5.7\%, mean intensity $6 \pm 7$ and mean abundance $0.34 \pm 7$ ) and Fuhrmanneta sp. (Davaineidae) (prevalence $2.85 \%$ and mean abundance $0.028 \pm 0.16$ ) and four nematodes, Baruscapillaria obsignata Madsen, 1945 (Capillariidae) (prevalence $51.42 \%$, mean intensity $29.72 \pm 44.2$ and mean abundance $15.28 \pm 34.7$ ); Ascaridia columbae (Gmelin, 1790) (Ascaridiidae) (prevalence $51.42 \%$, mean intensity $60.55 \pm 79.88$ and mean abundance $31.14 \pm 64.2$ ); Tetrameres fissipina Diesing, 1861 (Tetrameridae) (prevalence $14.28 \%$, mean intensity $346.3 \pm 504.4$ and mean abundance $49.42 \pm 212.1$ ) and Synhimanthus (Dyspharynx) sp. (Acuariidae) (prevalence 2.85\% and mean abundance $0.028 \pm 0.16$ ) (Table 1 ). 
Table 1. Prevalence, community status, amplitude of the intensity, mean intensity, mean abundance and site of infection of helminths present in Columba livia (Gmelin), in Municipality of Juíz de Fora, Minas Gerais, Brasil.

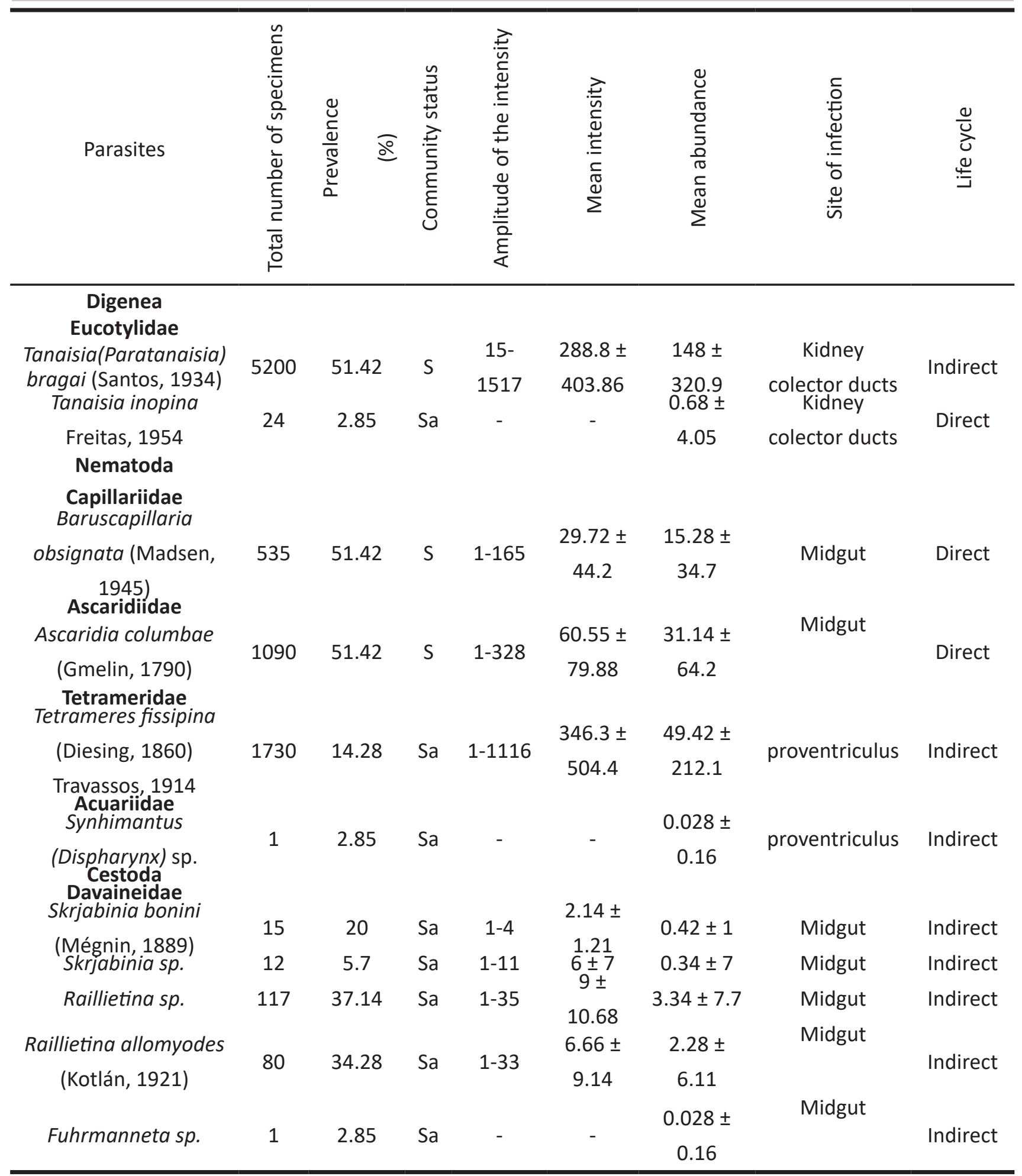


The helmith component community showed low concentration for dominance as demonstrated by Simpson's index ( $C=0.146)$. After calculating the value of importance of each species, T. (Paratanaisia) bragai, Raillietina sp., B. obsignata, T. fissipina and A. columbae were considered co-dominant species and T. inopina. Synhimanthus (Dyspharynx) sp., S. bonini, Skrjabinia sp., R. allomyodes e Fuhrmanneta sp. were considered unsuccessful species (Table 2).
Among the satellite species, Synhimanthus (Dyspharynx) sp. and Fuhrmanneta $\mathrm{sp}$. were the less prevalent. Only one female specimen of this nematode and fragments of the gravid proglotids of this cestode were found and, for this reason, it was unfeasible to accomplish their identification at species level.

All helminth species of the community showed aggregated distribution (Table 3). There was no significant association among species of

Table 2. Importance value attributed to the components of the helminth infracommunities present in Columba livia, in Municipality of Juiz de Fora, Minas Gerais, Brasil.

\begin{tabular}{ccc}
\hline Species & $\begin{array}{c}\text { Importance } \\
\text { value }\end{array}$ & Interpretation \\
\hline Tanaisia (Paratanaisia) bragai (Santos, 1934) & 0.7 & co-dominant \\
Tanaisia inopina (Freitas, 1951) & 0 & unsuccessful \\
Baruscapillaria obsignata (Madsen, 1945) & 0.07 & co-dominant \\
Tetrameres fissipina (Diesing, 1860) Travassos, 1914 & 0.06 & co-dominant \\
Ascaridia columbae Gmelin, 1790) & 0.14 & co-dominant \\
Synhimanthus (D.) sp. & 0 & unsuccessful \\
Skrjabinia bonini (Mégnin, 1889) & 0 & unsuccessful \\
Skrjabinia sp. & 0 & unsuccessful \\
Raillietina sp. & 0.11 & co-dominant \\
Raillietina allomyodes (Kotlán, 1921) & 0 & unsuccessful \\
Fuhrmanneta sp. & 0 & unsuccessful
\end{tabular}

There was no obvious separation of helminthes into core species. According to the classification proposed by BUSH \& HOLMES (1986), T. bragai, A. columbae and B. obsignata, most prevalent, were considered secondary species and T. inopina, T. fissipina, Synhimanthus (Dyspharynx) sp., S. bonini, Skrjabinia sp., $R$. allomyodes, Raillietina sp. and Fuhrmanneta sp. were considered satellite species. helminths.

\section{HELMINTH INFRACOMMUNITIES}

Infection by only one helminth species was detected in 10 hosts $29.41 \%$ of parasitized hosts). Infections by more than one helminth species were more frequent, occurring in $70.58 \%$ of the hosts. 
Table 3. Aggregated distribution pattern of the helminth infrapopulations present in Columba livia, in Municipality of Juiz de Fora, Minas Gerais, Brasil as demonstrated by the dispersion index.

\begin{tabular}{cc}
\hline Species & Dispersion index \\
\hline Tanaisia (Paratanaisia) bragai (Santos, 1934) & 693.37 \\
Tanaisia inopina (Freitas, 1951) & 24.19 \\
Baruscapillaria obsignata (Madsen, 1945) & 78.82 \\
Tetrameres fissipina (Diesing, 1860) Travassos, 1914 & 911.06 \\
Ascaridia columbae Gmelin, 1790) & 132.74 \\
Synhimanthus (D.) sp & 1 \\
Skrjabinia bonini (Mégnin, 1889) & 2.40 \\
Skrjabinia sp. & 10.17 \\
Raillietina sp. & 17.89 \\
Raillietina allomyodes (Kotlán, 1921) & 16.39 \\
\hline
\end{tabular}

Five hosts (14.7\%) were infected by two helminth species; seven hosts $(20.58 \%)$ by three species; five $(14.7 \%)$ by four species and seven $(20.58 \%)$ by five helminth species.

Infections by only one nematode species were more frequent (50\%) than infections by one cestode species (25\%) or one digenetic species (25\%). The presence of nematodes was registered in $80 \%, 87 \%, 100 \%$ e $100 \%$ of the infra communities composed by two, three, four and five helminth species, respectively.

Co-infection by two nematode species was more frequent (60\%) than co-infection by cestode and digenetic species $(20 \%)$ or by cestode and nematode species (20\%).

Cestodes were present in $40 \%$, $57.1 \%, 100 \%$ e $100 \%$ of the infra communities composed by two, three, four and five helminth species, respectively. Digenetic trematodes were present at $20 \%, 57.1 \%, 80 \%$ e $100 \%$ of the infra communities composed by two, three, four and five helminth species, respectively.

The helminth community showed low species richness (5). The number of species in the infracommunities varied between 1 to 5 species, $2.8 \pm 1.5$, in average. The mean diversity was 0.33 \pm 0.34 and maximum diversity was 1.06 .

\section{Discussion}

The component community was characterized by the co-dominance between $T$. bragai, Raillietina sp., B. obsignata, T. fissipina and A. columbae, the most prevalent and abundant species, and by the presence of unsuccessful or pioneer species: T. inopina, Synhimanthus (Dyspharynx) sp., S. bonini, Skrjabinia sp., R. allomyodes and Fuhrmanneta sp. 
Among the unsuccessful species were S. bonini and Synhimanthus (Dyspharynx) sp., helminthes that were previously reported in C. livia (Foggie 1933; Freitas 1946, 1957; GIOVANNONI 1946; GIOVANNONI \& KULLAK 1947; HWANG et al. 1961; MARTINS \& FREITAS 1975; ROLAS 1976).

The low prevalence of these species probably is related to a low ecological opportunity for infection, since these helminthes use intermediate hosts and thus the conclusion of their life cycles depends on the presence and abundance of these hosts in the environment. The biology of such parasites is influenced by complex ecological interactions and infecting the definitive host may be less favored in specific contexts.

The success of transmission by $T$. bragai, which also presents indirect life cycle, is enhanced by the capacity of the larval forms, present in the intermediate hosts, to reproduce asexually. The proliferation of the larva enhances the success of the infecting forms in colonizing the definitive host, resulting in an aggregated pattern of distribution of the sexual forms, favoring the genetic diversity and increasing the potential for adaptation to the host.

Helminth species previously described from other hosts, such as $R$. allomyodes and $T$. inopina, were also classified as unsuccessful or pioneer species. Raillietina allomyodes was described by KotLÁN (1921), infecting Psittaculirostris salvadorii, in New Guinea.
RoLAS (1976) reported this cestode species parasitizing C. livia in Brazil, however this author did not provide data on the prevalence or intensity of infection. Probably, $R$. allomyodes is a pioneer species in C. livia typical of infracommunities of other host species, since it was described in other continent, in a host phylogenetically distant of C. livia (LIVEZEY \& ZUSI, 2007).

Tanaisia inopina was described by FREITAS (1951) from specimens recovered from Passer domesticus, previously identified by AlmeIDa (1936) as T. zarudinyi. Later, Sterna sp., Icterus chrysocephalus and Coturnix japonica were registered as new hosts for this species by Freitas (1959), Franco (1965) and Pinto et al. (2005), respectively.

The parasitism by $T$. inopina in C. livia was not previously registered in the literature. This trematode probably is a pioneer species in C. livia, once it was found in low prevalence (only one host infected) and utilizes land snails as intermediate hosts, which also participate in the biological cycle of T. bragai (MALDONADO, 1945; Brasil \& Amato, 1992; Keller \& Araújo, 1992; BRANDOLINI et al. 1997).

The present work register for the first time the occurrence of $T$. inopina in Minas Gerais State and is the first account for the cooccurrence between T. bragai and T. inopina in the same individual host.

From the 140 adult trematodes found in the kidney collector ducts of one individual host, 
116 were identified as Tanaisia (Paratanaisia) bragai and 24 as Tanaisia inopina.

All the T. inopina specimens showed the uterus completely filled with eggs, indicating that its biological development was not harmed and thus this species probably presents potential for colonizing this new host species.

\section{REFERÊNCIAS BIBLIOGRÁFICAS}

ALMEIDA, J.L. 1936. Sobre alguns helmintos ainda não observados no Brasil. Revista do Departamento Nacional de Produção Animal 2: 415-416.

Amato, J.F.R., Boegue, \& AMAto, S.B. 1991. Protocolos para laboratório - coleta e processamento de parasitos do pescado. Imprensa Universitária Universidade Federal Rural do Rio de Janeiro, Seropédica, $81 \mathrm{p}$.

Brandolini, S.V.P.B., Amato, S.B. \& Pereira, A.A.. 1997. Relacionamento de Tanaisia bragai (Digenea, Eucotylidae) e seu hospedeiro intermediário, Subulina octona (Gastropoda, Subulinidae) sob condições experimentais. Parasitologa al Día 21: 2026.

BRASIL, M.C. \& AMATO, S.B.. 1992. Faunistic analysis of the helminths of sparrows (Passer domesticus L. 1758) captured in Campo Grande, Rio de Janeiro, RJ. Memórias do Instituto Oswaldo Cruz 87: 43-48.
Bush, A.O. \& Holmes, J.C. 1986. Intestinal helminths of lesser scaup ducks: an interactive community. Canadian Journal of Zoology 64: 142-152.

BUSh, A.O., LAFFERTY, K.D., LOTZ, J.M. \& ShOSTAK, A.W. 1997. Parasitology meets ecology in its own terms: Margolis et al. revisited. Journal of Parasitology 83: 575-583.

Carneiro, J.R., lustosa, E.S., Pereira, E., Carvalho, E.D. \& NÁPoli, M.A. 1975. Incidência de ecto e endoparasitos de pombos (Columba livia domestica) em Goiânia. Revista de Patologia Tropical 4: 39-41.

CostA, H.M.A. \& FreitAS, M.G. 1970. Lista dos helmintos parasitos dos animais domésticos do Brasil. Arquivos da Escola de Veterinária 22: 33-93.

CostA, H.M.A., Leite, A.C.R., GuimarÃes, M.P. \& LIMA, W.S. 1986. Distribuição de helmintos parasitos de animais domésticos no Brasil. Arquivos Brasileiros de Medicina Veterinária e Zootecnia 38: 465-579.

FogGIE, A. 1933. On a cestode parasite of the domestic pigeon (Columba livia). The Annals and Magazine of Natural History 10: $168-172$.

Franco, S.R.N. 1965 Nota sobre trematódeos eucotilídeos (Trematoda, Eucotylidae). Memórias do Instituto Oswaldo Cruz 63: $59-65$. 
FREITAS, M.G. 1946. Sobre um cestóide de pombo doméstico em Minas Gerais - Brasil. Congresso Brasileiro de Veterinária 10: 256-258.

FREITAS, J.F.T. 1951. Revisão da família Eucotylidae Skrjabin, 1924 (Trematoda). Memórias do Instituto Oswaldo Cruz 49: 34 - 123.

FREITAS, M.G. 1957. Lista dos helmintos parasitos dos animais domésticos de Minas Gerais. Arquivos da Escola de Veterinária 10: 373381.

FREITAS, J.F.T. 1959. Nota sobre Tanaisia inopina Freitas, 1951 (Trematoda, Eucotylidae). Atas da Sociedade de Biologia do Rio de Janeiro 3: 2-4.GIOVANNONI, M. 1946. Fauna parasitológica paranaense. III. Raillietina (Skrjabinia) bonini (Mégnin, 1889) em pombos domésticos. Arquivos de Biologia e Tecnologia 1: 29-31.

Giovannoni, M. \& KULLAK, G.V.L. 1947. Fauna parasitológica paranaense. IV. Lista de helmintos em animais domésticos. Arquivos de Biologia e Tecnologia 2: 225-232.

HWANG, J.C., Tolgay, N., Shalkop, W.T. \& JAQuetTe, D.S. 1961. Case report - Dispharynx nasuta - causing severe proventriculitis in pigeons. Avian Diseases 5: 60- 65.

Keller, D.G. \& Araújo, J.L.B. 1992. Ciclo evolutivo de Paratanaisia bragai (Santos 1934) (Trematoda, Eucotylidae) com novo hospedeiro intermediário no Brasil: Leptinaria unilamellata (d`Orbigny, 1835)
(Gastropoda, Pulmonata, Subulinidae) em condições de laboratório. Revista Brasileira de Parasitologia Veterinária 1: 82-92.

KotláN, A. 1921. Uj-Guinea Mádar-Cestodák. I. Papagály - Cestodák. Annales Historiconaturales Musei Nationalis Hungaricae 18: 1-27.

LIVEZEY, B.C. \& ZUSI, RL. 2007. Higher-order phylogeny of modern birds (Theropoda, Aves: Neornithes) based on comparative anaomy. II. Analisis and Discussion. Zoological Journal of the Linnean Society 149 (1): 1-95.

Maldonado, J.F. 1945. The life cicle of Tarmelanea bragai Santos, 1934 (Eucotylidae), a kidney fluke of domestic pigeons. Journal of Parasitology 31: 306-314.

Martins, J.W. \& FreitAS, M.G. 1975. Lista de helmintos parasitos de animais domésticos da região geoeconômica de Brasília e de outras regiões de Goiás. Arquivos da Escola de Veterinária 27: 309-324.

Pinto, R.M., Menezes, R.C., TORTelly, R. \& NoRONHA, D. 2005. First report of a natural helminth infection in the japanese quail Coturnix japonica Temminck \& Schlegel (Aves, Phaisanidae, Galliformes) in the Neotropical region. Revista Brasileira de Zoologia 22: 836-838.

RoLAS, F.J.T.S. 1976. Contribuição para o conhecimento de alguns cestódeos do gênero Raillietina Fuhrmann, 1920, 
(Cestoda-Davaineidae), parasitos de Columbiformes. Memórias do Instituto Oswaldo Cruz 74: 65- 70.

SANTOS, V. 1934. Monostomose renal das aves domésticas. Revista do Departamento Nacional de Produção Animal do Brasil 1: 203-215.

Silva, C.C., MATTOS-JÚNIOR, D.G. \& RAMIRES, P.M. 1990. Helmintos parasitas de Columba livia (Gm) no município de São Gonçalo, Rio de Janeiro. Arquivo Brasileiro de Medicina
Veterinária e Zootecnia 42: 391-394.

Thul, J.E., Forrester, D.J. \& ABercrombie, C.L. 1985. Ecology of parasite helminths of wood ducks, Aix sponsa, in the Atlantic Flyway. Proceedings of the Helminthological Society of Washington 52: 297-310.

Recebido: 04/04/2016

Revisado: 04/08/2016

Aceito: 27/09/2016 